\title{
FROM A SON OF MARCO POLO IN THE VILLAGE OF BLUE PEOPLE
}

\author{
After Nora Sturges's paintings "Marco Polo Watches Blue People" \\ and "At the End of the Desert, You Arrive at Karkan, Where There Is \\ Two of Everything"
}

What would I have done

on that clear day in the past

while I practiced to improve my skills

at soccer, catch, or stickball

on the banks of a stream so clear

I could see myself in it,

if I'd found my father watching? Not

the man I called my father,

who shared his bagel gladly

and gave pointers on my swing,

but a man I'd never met, some stranger

who hung back and eavesdropped

behind trees and water-weeds?

What would I have said?

I wouldn't have been surprised, my skin

not even really blue

but the color of our cat:

diluted, light gray, coffee-tinged

-Was I her offspring, kids at school would laugh,

so different from my parents,

whose own skin at midsummer

burned to true cerulean.

THE IOWA REVIEW 
Would I have shouted, Show yourself,

quit your furtive lurking,

declare your true intention

as a father or a friend?

Or would I have left, ashamed, my mother's

long-rehearsed evasions

explaining far too much?

- Marco Polo, these are questions

I must put to you today. Your yellowed

postcard-scrawled in haste,

ink-blotched, ambiguous-

tells me nothing of your life

as Kubla Khan's ambassador, or father

of more sons and daughters

than you'll ever know.

An orange sheet dries on the line,

tomatoes ripen on the windowsill-

and, inside, Mother weeps

not for your memory,

Marco Polo, long ago

fled into shadow, but for the grief she knew

in hiding you from me,

for her husband's love

and full devotion to her son,

and for this last, hard choice: to share her evidence

of you, postmarked Karkan, 
Some Other Era, when

a man did as he pleased on journeys

of discovery. One day, I, too,

will leave this village, bid

farewell to quiet days,

the blue sky mirroring our skin,

the clear stream and the evergreens; and, yes,

this woman who connects us

to each other and herself,

and, finally, to something larger:

the fragile human family. Till then,

I only have your postcard,

16

with its clues to who I am

and who you are, absent Father,

famed explorer far away, its haunting

image of Karkan

inviting my departure

with its lush, unearthly beauty:

palm trees, fruit, blood-orange sand-a paradise, perhaps, that's yours, or mine. 